\title{
BRICS COOPERATION IN SCIENCE, TECHNOLOGY AND INNOVATION: PROGRESS TO BE SHOWN ${ }^{1}$
}

\author{
Luis Claudio Kubota²
}

Cooperation in science, technology and innovation is a theme that has been discussed by BRICS in the last few years for its relevance in the current international panorama of the 21st century. However, each country has shown itself to be different, in a matter of progress: some have excelled more successfully than others in each field of development. This paper presents the progress of BRICS cooperation in Science, Technology and Innovation over the years, highlighting each country's development and also comparing the block's improvement to other countries and blocks throughout the world. The analysis brings, in each section, possible pathways for BRICS in the discussed topics.

Keywords: BRICS; science; technology; innovation; research and development; cooperation.

\section{PROGRESSOS DO BRICS NA COOPERAÇÃO EM CIÊNCIA, TECNOLOGIA E INOVAÇÃO}

A cooperação em ciência, tecnologia e inovação é um tema que tem sido discutido pelos BRICS nos últimos anos pela sua relevância no atual panorama internacional do século XXI. No entanto, cada país mostrou-se diferente, em questão de progresso: alguns se destacaram mais do que outros em cada área de desenvolvimento. Este artigo apresenta o progresso da cooperação dos BRICS em Ciência, Tecnologia e Inovação ao longo dos anos, ressaltando o desenvolvimento de cada país e também comparando a sua evolução com a de outros países e blocos em todo o mundo. A análise trazida em cada seção mostra os possíveis caminhos para os BRICS nos assuntos abordados.

Palavras-chave: BRICS; ciência; tecnologia; inovação; pesquisa e desenvolvimento; cooperação.

\section{AVANCES EN LA COOPERACIÓN DEL BRICS EN CIENCIA, TECNOLOGÍA E INNOVACIÓN}

La cooperación en materia de ciencia, tecnología e innovación ha sido discutida por el BRICS en los últimos años por su relevancia en el panorama actual internacional. Sin embargo, cada uno de los países ha tenido diferentes niveles de progreso en las diferentes áreas del desarrollo. Este artículo presenta los avances en la cooperación del BRICS en las áreas de ciencia, tecnología e innovación a través de los años, destacando el desarrollo de cada país y comparando también su evolución con la de otros países y bloques del mundo. El análisis aportado en cada sección muestra posibles caminos para el BRICS en los temas abordados.

Palabras clave: BRICS; ciencia; tecnología; innovación; investigación y desarrollo; cooperación. JEL: 03; F50,

Data de envio do artigo: 10/3/2020; Data de aceite: 24/3/2020.

1. The author would like to thank Carlos Matsumoto (MCTIC), André Rauen (Ipea) and the anonymous referee for their suggestions. Any errors are attributable to the author.

2. Researcher at the Directorate of Sectorial Policies and Studies, Innovation and Infrastructure (Ipea).

E-mail:<luis.kubota@ipea.gov.br>. 


\section{INTRODUCTION}

In 2015, the BRICS Think Tanks Council (BTTC) published a chapter on knowledge sharing and innovation by BRICS. Data showed that BRICS had much worse indicators than Triadic countries and that, among BRICS, China had the far best indicators (BRICS Think Tanks Council, 2015).

The Global Innovation Index is developed by Cornell University, INSEAD and the World Intellectual Property Organization (WIPO). Its framework take several dimensions into account. Among the innovation input dimensions: institutions, human capital and research, infrastructure, market sophistication and business sophistication. On the one hand, analysis by Kubota (2018) shows that the gap between China and other BRICS countries have not decreased since the BTTC 2015 publication. China's rise in the index has been classified as "spectacular" by Global Innovation Index organizers. On the other hand, two important things have changed since 2015.

The first one was the election of President Donald Trump in the United States. As China has differentiated from other BRICS by increasing its global innovation influence (Wang and Li-Ying, 2014), President Trump has elected the eastern country as a main rival, both in trade and technological affairs. The second is that the cooperation on science and technology among BRICS has shown progress, as it will be shown later in this article.

With globalization, two elements emerged in National Innovation Systems. The first is foreign-located but domestically owned $R \& D$ and the second is domestically located but foreign-owned $\mathrm{R} \& \mathrm{D}$. As a result, countries have become increasingly interdependent in their R\&D activity (Wang and Li-Ying, 2014). This interdependence must be taken into account by countries considering partnerships in science, technology and innovation.

The aim of this article is to present the current situation of BRICS cooperation on science, technology and innovation (ST\&I), comparing it with the much older and more consolidated cooperation in the European Union (EU). This analysis can highlight possible pathways for BRICS. The chapter is organized as follows. The second section presents BRICS indicators of ST\&I, with an emphasis on cooperation. The third section presents relevant aspects of cooperation on ST\&I for the European Union. The fourth section presents relevant aspects of cooperation on ST\&I for BRICS as a block. The fifth section provides a comparison between the two case studies and the sixth the concluding remarks. 


\section{BRICS INDICATORS OF ST\&I}

This subsection brings some data on BRICS performance on ST\&I, with emphasis on cooperation (graphs 3, 4 and 5). Graphs 1 and 2 show that BRICS did not change much their position with regard to the two indicators analysed: research per thousand employed and gross domestic expenditures on $\mathrm{R} \& \mathrm{D}$ as a percentage of GDP. Graph 2 shows that, in 2015, China spent more than the combined EU28 area, in US\$ PPP: 409 billion against 386 billion, respectively (OECD, 2017). The same graph shows that Brazil and Russia have similar expenditures in R\&D relative do GDP, even though Russia has a much larger percentage of researchers in its workforce. India and South Africa have similar expenditures in $R \& D$ relative do GDP.

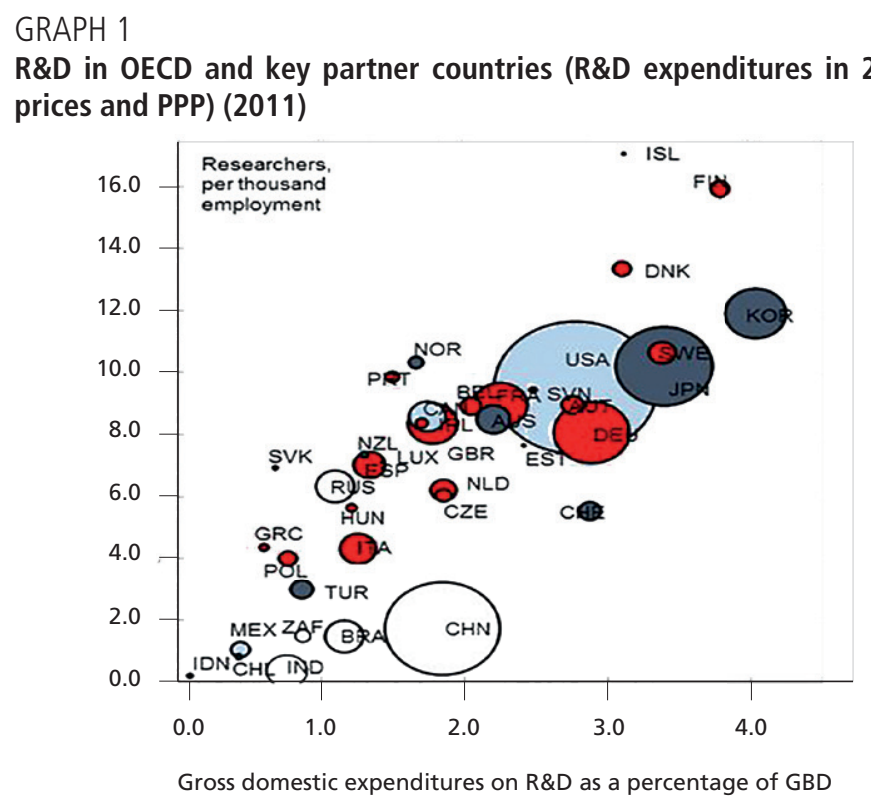

Source: OECD. Available at: <www.oecd.org/sti/msti.htm>; and Brazil and UNESCO, 2013.

From an output perspective, investigation by Kahn (2015) shows that BRICS countries have low level of scientific cooperation. In absolute terms, data from the databases investigated by Kahn (Web of Science, Scopus and others), show that China had the largest number of publications, followed by India, Brazil, Russia and South Africa. On the other hand, South Africa had the largest proportions of co-publications with other BRICS. Moreover, China is the main partner of co-publications with the other BRICS. Kahn (2015) adds that BRICS countries had much larger co-publications both with scientists from the United States and European Union. 


\section{GRAPH 2}

$R \& D$ in OECD and key partner countries (R\&D expenditures in 2010 USD constant prices and PPP) (2015)

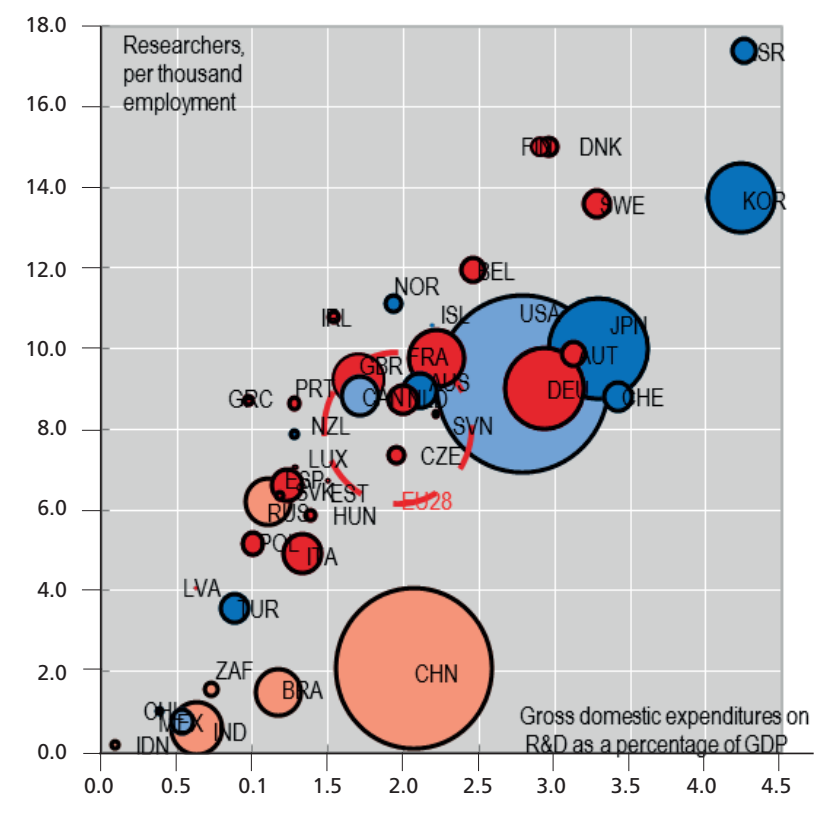

Gross domestic expenditures on R\&D as a percentage of GDP

\section{BRICS North America \\ European Union \\ Other OECD members}

Source: OECD. Available at: <http://oe.cd/msti>; and UNESCO, 2017.

These results are similar to the ones found in the BRICS Innovative Competitiveness report 2017: the share of Chinese publications co-authored with researchers from BRICS countries in the total number of internationally co-authored publications is 3\%; for Brazil, 9\%, for Russia, $10 \%$, for India, $11 \%$, and for South Africa, 15\% (BRICS, 2017b).

Graph 3 shows that India is the only BRICS country that has a larger proportion of co-inventions than co-authorship. Factors such as the size of the country, scientific and technological specialization, collaboration opportunities, geographical and institutional proximity help explain the patterns shown in the graph (OECD, 2017). Russia also has a high indicator for co-inventions, and South Africa is close to the median, both for co-invention and co-authorship.

Graph 4 displays international scientist mobility, and it shows that China has become the largest net recipient of scientists, among major economies. India has accumulated net losses, while Russia began to attract scientists since 
2014. Mobility can only be calculated for authors with at least two publications (OECD, 2017).

GRAPH 3

International collaboration in science and innovation (co-authorship and co-invention as a percentage of scientific publications and IP5 patent families) (2005-2016)

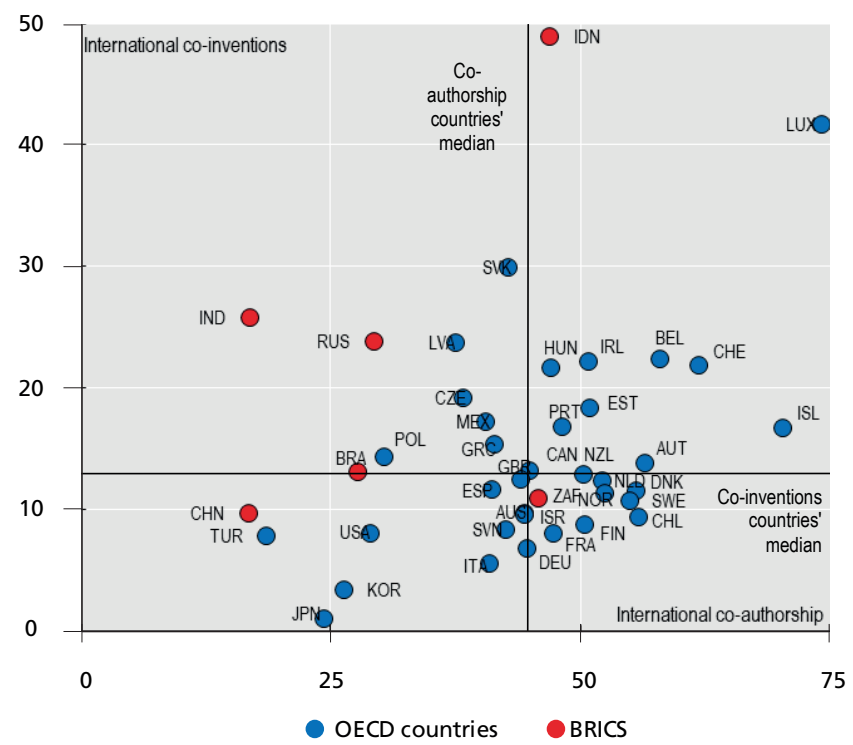

Source: OECD, 2017. Available at: <http://oe.cd/ipstats>.

GRAPH 4

International net flows of scientific authors, selected economies (difference between annual fractional inflows and outflows, as percentage of total flows) (2002-2016)

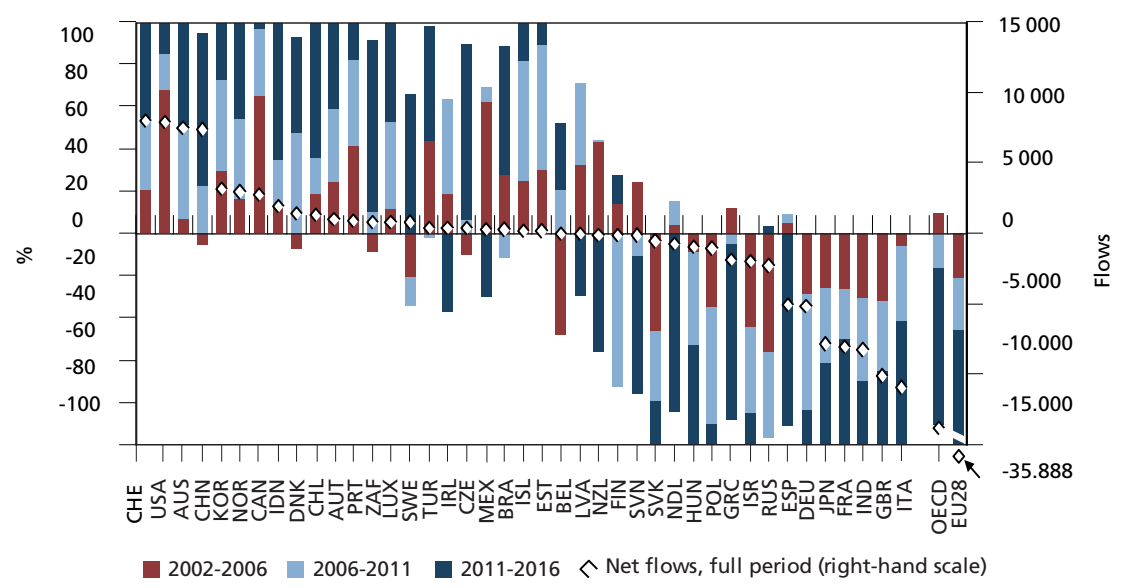


Considering the impact and collaboration, graph 5 shows that all BRICS countries are classified in the quadrant "low collaboration - low quality", meaning that, in general, the scientific production of these countries are not among the most influential in their subject areas.

\section{GRAPH 5}

The citation impact of scientific production and the extent of international collaboration (as an index and percentage of all citable documents, based on fractional counts) (2012-2016)

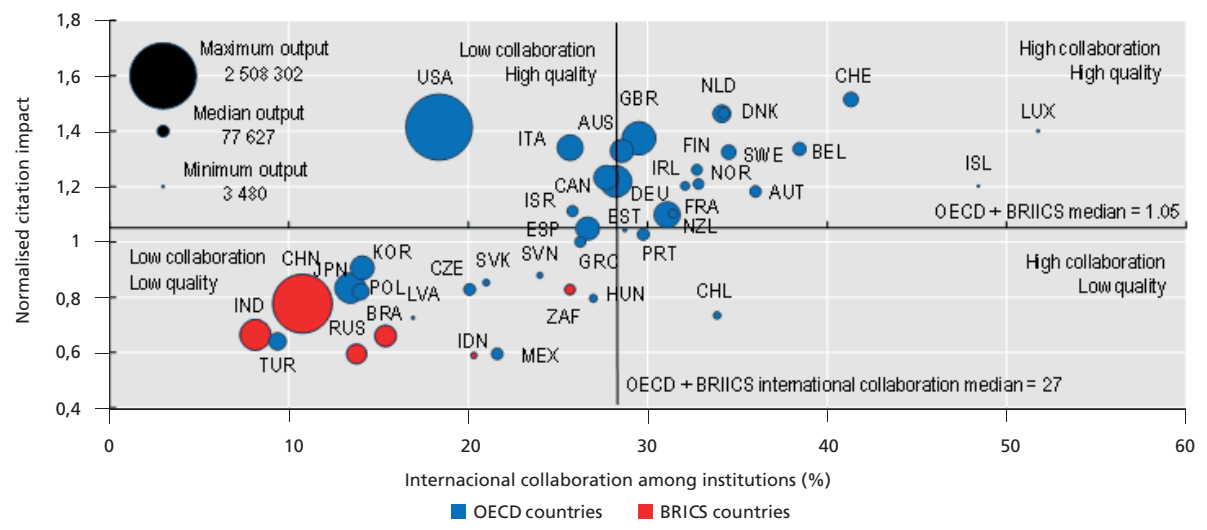

Source: OECD, 2017.

\section{RELEVANT ASPECTS OF COOPERATION ON ST\&I FOR THE EUROPEAN UNION}

This section aims to highlight relevant aspects of cooperation on ST\&I in the European Union. It is probably the most relevant cooperation in the world, and one of its programs has already served as a source of inspiration for the BRICS partnership. European research organizations such as European Nuclear Research Centre (CERN) and European Molecular Biology Organization (EMBO) were founded in 1954 and 1964, respectively. The European Cooperation in Science and Technology (COST) was established in 1971 (Okamoto and Fukasako, 2012). COST is a framework supporting the networking of researchers. It receives and organizes the evaluation and selection of proposals and manages the funded COST actions (Alföldi, 2017).

Currently, COST has 28 full members from the EU, five EU candidates and potential candidates, three other countries and one cooperating member. COST objectives include: strengthening the excellence through cross-border networking of researchers, empowering researchers from less connected innovation ecosystems and promoting geographical, age and gender balance throughout its activities and operations (Alföldi, 2017).

In 2017, COST promoted 347 actions, 266 training schools, 2962 short term visits, 45.000 researchers, had an average of 129.000 euros per COST 
action and a budget of 37.500 .000 euros. COST action proposals must have a minimum of 7 COST full members, as well as a minimum of inclusiveness target countries (Alföldi, 2017).

The European Patent Organization is an intergovernmental organization that was set up in October 1977, based on the European Patent Convention (EPC), signed in Munich in 1973. The organization has 38 member states, having as mission to grant European patents in accordance with the EPC. ${ }^{3}$

EUREKA focuses on creating intergovernmental network to support market oriented research and innovation projects by enterprises, research institutes and universities in 39 countries (EUREKA, 2015). The program was created in 1985 as an intergovernmental initiative, aiming to promote closer cooperation among enterprises and research institutes in the field of advanced technologies, in order to increase productivity in Europe (Bayona-Sáez and García-Marco, 2010).

The structure of the program is bottom-up, meaning that project participants mainly small and medium enterprises (SMEs) - determine the way the project develops, its duration and the amount invested. A project is implemented by at least two partners located in at least two of the current member countries, and aims at developing an innovative product, process or service, with a clear market oriented bias (Bayona-Sáez and García-Marco, 2010).

EUREKA has simple rules and limited bureaucracy, allowing very rapid processing of proposals. In $60 \%$ of cases, EUREKA is able to assign its label within just four months of the project submission date. An evaluation of the program found positive impacts of EUREKA Program on performance of participating firms, measured by the return over assets (Bayona-Sáez and García-Marco, 2010).

The Framework Programmes for Research (FP) were already mentioned in the BTTC 2015 report (BRICS Think Tanks Council, 2015). The first FP was launched in 1984. The multiannual FP are not bottom-up like COST or EUREKA, but, instead, have well-defined objectives and programme themes and details, being previously negotiated with member states and the European Parliament. Promoting transnational mobility of researchers has been a major objective of the FP, and they are administered by the European Commission (Okamoto and Fukasako, 2012).

Horizon 2020 is the biggest EU research and innovation programme ever, with a budget of almost 80 billion euros of funding for the period 2014 to 2020. Horizon 2020 has the political backing of Europe's leaders and the members of the European Parliament. Its goal is to ensure Europe produces world-class science, removing barriers to innovation and making it easier for the public and private sector to innovate. ${ }^{4}$

3. See: <https://www.epo.org/index.html>.

4. See: <https://ec.europa.eu/programmes/horizon2020/what-horizon-2020>. 
The European Institute of Innovation and Technology (EIT) was created in 2008 to support the development of pan-European partnerships between leading universities, research labs and companies. These partnerships are known as EIT Innovation Communities. The EIT headquarters are based in Budapest, with facilities in many other European cities, specialized in the following areas of research: digital technologies, food, health, energy, manufacturing, raw materials and urban mobility. ${ }^{5}$

\section{RELEVANT ASPECTS OF COOPERATION ON ST\&I FOR BRICS COUNTRIES}

In this subsection, the recent history of BRICS scientific and technological cooperation as a block will be briefly presented, without considering bilateral agreements or other blocks like IBSA (India, Brazil and South Africa).

On September 2011, Russia took the initiative to promote the first BRICS Senior Official meeting on scientific cooperation. The meeting had the intent to promote cooperation in innovation projects in fields like: microelectronics, nanotechnologies and materials, biotechnologies, energy efficiency technologies and renewable energy, research on climate change, and, as mandated by the Heads of State and Government of BRICS nations, the meeting would also consider establishing a working group on pharmaceutical industry (BRICS, 2011).

The First BRICS Science, Technology and Innovation Ministerial Meeting happened in February 2014, in Cape Town. Beyond more generic and diplomatic statements, the five countries agreed on the following main areas of cooperation: exchange of information on policies and programmes ${ }^{6}$ and promotion of innovation and technological transfer; food security and sustainable agriculture; climate change and natural disaster preparedness and mitigation; new and renewable energy; energy efficiency; nanotechnology; high performance computing; basic research; space research and exploration, aeronautics, astronomy and earth observation; medicine and biotechnology; biomedicine and life sciences (biomedical engineering, bioinformatics, biomaterials); water resources and pollution treatment; high tech zones/sciences parks and incubators; technology transfer; science popularization; information and communication technology; clean coal technologies; natural gas and non-conventional gases; ocean and polar sciences; and geospatial technologies and its applications (BRICS, 2014).

As a first step, the ministers endorsed the establishment of five thematic areas and leadership: climate change and natural disaster mitigation (Brazil), water resources and pollution treatment (Russia), geospatial technology and its applications (India), new and renewable energy, energy efficiency (China), astronomy (South Africa) (BRICS, 2014).

5. See: <https://eit.europa.eu>.

6. It is interesting to note that this chapter contributes to this objective. 
In March 2014, the BRICS Seminar on National Innovation Systems was held in Brasilia. In May 2014, it happened the 1st Workshop on Prevention and Mitigation of Natural Disasters, held in the same city. In June 2014, the International Conference on Water Management and Ecology, in the framework of the Russian participation in BRICS was held in Moscow. In November 2014, the Meeting of BRICS Solid Lightning Working Group was held Guanzhou (Brasil, 2015).

A Memorandum of Understanding on Cooperation in Science, Technology and Innovation (MoU) was signed in Brasília, in March 2015. In the MoU, the countries agreed to develop a work plan 2015-2018, encompassing the launch of BRICS Research and Innovation Initiative (BRICS R\&I Initiative), which should cover actions including: cooperation in the framework of major research infrastructures; coordination of existing large scale national programmes of BRICS countries; setting up a Framework for funding multilateral joint project for research, technology commercialization and innovation; establishing a joint Research and Innovation Networking Platform (Brasil, 2015).

The modalities of cooperation cited in the MoU were: short-term exchange of scientists, researchers; dedicated training programmes to support human capital development in ST\&I; organization of ST\&I innovation workshops, seminars and conferences in areas of mutual interest; exchange of ST\&I information; formulation and implementation of collaborative research and development programmes and projects; establishment of joint mechanisms to support BRICS research programmes and large-scale research infrastructure projects; facilitated access to S\&T infrastructure among BRICS member countries; announcement of simultaneous calls for proposals in BRICS member countries; cooperation of national science and engineering academies and research agencies (Brasil, 2015).

The MoU also mentioned the structures of governance of the partnership: BRICS Science, Technology and Innovation Ministerial Meeting, BRICS Science, Technology and Innovation Senior Officials Meeting and BRICS Science, Technology and Innovation Working Group, with specific responsibilities for each one of them (Brasil, 2015).

In Brasília the following events were announced: 1st Meeting of the BRICS Working Group on Astronomy, in South Africa; International Scientific and Experimental Conference on Water, in Russia; Technologies, Materials in Industry and Energy Processes, in Russia; 2nd Meeting of the BRICS SSL Working Group, in China; BRICS Working Group on Geospatial on Technology Application for Development, in India. BRICS also agreed a Brazilian-Russian proposal to start negotiations with the view to establishing biomedicine and life sciences as a new priority area for cooperation. BRICS countries also agreed 
to create a BRICS Young Scientists Forum ${ }^{7}$ proposed by India. BRICS also committed to the BRICS Economic Partnership Strategy, which should include Science, Technology and Innovation as a priority (Brasil, 2015).

The First Meeting of the BRICS STI Funding Parties on the establishment of the BRICS R\&I Initiative was held in July 2015, in Moscow. In Russia's capital, BRICS countries committed to develop and implement the BRICS Framework Programme on multilateral research funding through joint calls. Besides initiatives proposed before (BRICS Young Scientists Forum - India as coordinator - and Cooperation on Biotechnology and Biomedicine including Human Health and Neuroscience - Brazil and Russia as coordinators), new initiatives were announced: Cooperation on Information Technologies and High Performance Computing (China and South Africa as coordinators), Cooperation on Ocean and Polar Science and Technology (Brazil and Russia as coordinators), Cooperation on Material Science including nanotechnology (India and Russia as coordinators), Cooperation on Photonics (India and Russia as coordinators) (BRICS, 2015).

BRICS countries acknowledged independent initiatives to establish the BRICS Network University aimed at developing master's and $\mathrm{PhD}$ programmes along with joint research projects in the main areas of cooperation. Many events were announced in the Moscow Declaration: a BRICS thematic Session on Prevention and Mitigation of Natural Disasters (hosted by Brazil and India) in the 6th Annual Conference of the International Society for Integrated Disaster Risk Management (Saint Petersburg), the 2nd Meeting of BRICS Solid-state lightning (SSL) Working Group in China, the first meeting of the BRICS Astronomy Working Group in South Africa, the BRICS Working Group on Geospatial Technology Application for Development in India, the 2nd Meeting of the Group of STI Funding Parties in Russia (BRICS, 2015).

In January 2016 it was signed the Arrangement of the BRICS STI Framework Program and the Implementation Plan (BRICS Arrangement). This arrangement was instrumental to the countries' joint research and innovation funding in priority areas materialized in the 1st BRICS Pilot Call 2016. India proposed to establish a BRICS Science and Technology Driven Entrepreneurship and Partnership initiative (BRICS, 2016).

In 2017, BRICS countries agreed to adopt the BRICS Action Plan to Innovation Cooperation. The countries agreed to "promote entrepreneurship and build platforms in BRICS countries and mainly collaborate in technology cooperation, technology transfer and translation, science and technology parks, youth innovation and entrepreneurship and in fostering strategic and long term

7. It was initiated at the Second BRICS Science, Technology and Innovation Ministerial Meeting in Brasilia, aiming at increasing BRICS connectivity of youth between 22 to 35 years from science, engineering and other disciplines. 
university-industry partnerships so as to build sound ecosystems for innovation and entrepreneurship" (BRICS, 2017a).

In 2018, BRICS countries also supported the need for a dedicated Call for proposals on flagship BRICS R\&D projects in disruptive technologies that strategically positions the BRICS countries for leadership in the Fourth Industrial Revolution, and endorsed the initiative to investigate the feasibility of establishing a permanent mechanism to manage and coordinate BRICS STI activities (BRICS, 2018).

The 2nd BRICS STI Framework coordinated call occurred in 2017. A list of many other events that happened in 2017 and 2018 can be seen in figure 1 .

FIGURE 1

Chronology of main events in BRICS cooperation (2011-2018)


Prepared by author.

Obs.: Not an exhaustive list. 


\section{COMPARISON BETWEEN THE TWO CASES}

The long and mature ST\&I cooperation of the European Union serves as reference for other blocks, like Asia-Pacific Economic Cooperation - APEC (Okamoto and Fukasako, 2012), and can also be useful for BRICS countries. Comparing with the EU, BRICS countries have evolved in the science and technology cooperation consider the BRICS STI Framework Programmes, but not as much in the innovation agenda. BRICS countries still have low levels of scientific cooperation, meaning there is much room for deeper scientific exchanges.

Table 1 resumes some of the main differences between the two case studies.

TABLE 1

Comparison of European Union and BRICS cooperation on science, technology and innovation

\begin{tabular}{|c|c|c|}
\hline Characteristics & European Union & BRICS \\
\hline Maturity of cooperation & $\begin{array}{c}\text { Formal and effective cooperations since } \\
\text { 1950's, with the foundation of the } \\
\text { European Nuclear Research } \\
\text { Centre (CERN) }\end{array}$ & $\begin{array}{l}\text { First meeting occurs in 2011, but cooperation takes } \\
\text { impulse in 2014, with the Cape Town declaration }\end{array}$ \\
\hline Context of integration & $\begin{array}{l}\text { One of the most integrated blocks, with } \\
\text { the existance of the European Comission } \\
\text { and a Parliament, besides free trade } \\
\text { arrangements and free flow of citizens. } \\
\text { Common currency for most of } \\
\text { the countries }\end{array}$ & $\begin{array}{l}\text { Relatively recent block, with focus on South-South } \\
\text { cooperation. Development bank created by the } \\
\text { member countries }\end{array}$ \\
\hline Geographical context & Geographically concentrated countries & Countries spread in four continents \\
\hline Resources & Investments of billions of euros & Investments of millions of dollars \\
\hline Institutions & $\begin{array}{c}\text { European Union, European Patent } \\
\text { Organization, European Institute of } \\
\text { Innovation and Technology, besides large } \\
\text { infrastructures like CERN }\end{array}$ & $\begin{array}{l}\text { Programs managed directly by the governments } \\
\text { and agencies }\end{array}$ \\
\hline Programs & $\begin{array}{l}\text { Great variety of programs, including } \\
\text { research, exchange and innovation }\end{array}$ & $\begin{array}{l}\text { Programs devoted to research and exchange. } \\
\text { Programs devoted to innovation still incipient }\end{array}$ \\
\hline Studies about cooperation & $\begin{array}{l}\text { Vast literature, including } \\
\text { impact evaluation }\end{array}$ & Incipient \\
\hline Vision & European leadership & - \\
\hline
\end{tabular}

Prepared by author.

BRICS is a relative recent block of countries, and its scientific cooperation has taken impulse from 2014 on. It is a great contrast with the European cooperation, which dates from the 1950's. As a result, there is a vast literature about the European cooperation, while in the BRICS case this literature is still scarce.

The European Union is one of the most integrated blocks in the world, with the European Commission and a Parliament, free trade arrangements, free flow of citizens and a common currency for most countries. The main institutional accomplishment of the BRICS block is probably the creation of the New Development Bank. 
European Union members are concentrated geographically, whereas BRICS countries are spread in four different continents. Budgets for the joint programs in Europe involve billions of euros, while the BRICS joint investments are measures in millions of dollars.

Considering innovation, EU developed three important features of its regional innovation system. The first one is in the creation of the European Patent Organization. The second one is the EUREKA program, focusing on creating intergovernmental network to support market-oriented research and innovation projects by enterprises, research institutes and universities. The third one is the European Institute of Innovation and Technology.

In Europe there is a great variety of programs, including research, exchange and innovation, whereas in the BRICS case innovation cooperation is still incipient.

The European cooperation is part of a much greater framework, and has the vision of European leadership in ST\&I. Based on figures shown before in the article, this ambition is something that, in the current situation, might apply to China, but not to the other BRICS countries.

Given all these major differences, BRICS cooperation in ST\&I may follow some of the paths taken by Europe, but not others. Nevertheless, patent integration, programs devoted to the introduction of innovation in the market and a joint institute of technology might be developments that BRICS countries should consider as the cooperation evolves. Currently, BRICS programs are directly managed by the governments and agencies.

\section{CONCLUDING REMARKS}

Analysis of ST\&I indicators showed that, in 2015, China spent more than the combined EU28 area, in US\$ PPP. India and Russia have high levels of international co-inventions. South Africa has the larger proportion of co-authorships, with BRICS partners and others. Considering BRICS and OECD countries, the scientific production of the first ones are classified as "low collaboration - low quality (impact)".

Documental analysis of the BRICS declarations and other documents on cooperation in science and technology presented in section 4 of this chapter showed a clear path of evolution. A governance for the partnership and areas of interest was established. Many proposals by individual or the five countries together became reality. Among the concrete examples that deserve being mentioned are: active working groups and meetings on several areas of interest, the BRICS GRAIN (Research Infrastructure Platform), ${ }^{8}$ and the BRICS STI Framework Program,

8. Available at: <https://brics-grain.org/>. 
which received 462 proposals for the 2nd BRICS STI Framework Programme Call 2017. .' In the bibliometric literature, BRICS countries are increasingly becoming a unit of analysis, especially in the health area. It seems clear that the seed planted only a few years ago has grown, is giving fruits and multiplying.

With regard to innovation, the author recommends that when BRICS countries consider the development of programs, they should have an emphasis on the market, with enterprises in the center stage, not Academia. Small and medium enterprises should have a strong participation, and EUREKA is a good example.

\section{REFERENCES}

ALFÖLDI, K. COST - European cooperation in science and technology: introduction to the COST Framework Programme. Brussels: COST, 2017. Available at: <https:// www.ukro.ac.uk/aboutukro/Documents/170623_ukro_conference_alfoldi.pdfs.

BAYONA-SÁEZ, C.; GARCÍA-MARCO, T. Assessing the effectiveness of the Eureka Program. Research Policy, v. 39, n. 10, p. 1375-1386, 2010.

BRASIL. Ministério das Relações Exteriores. Second BRICS science, technology and innovation ministerial meeting: Brasília declaration. [s.l.]: MRE, 2015. Available at: <http://www.itamaraty.gov.br/en/press-releases/8911-ii-bricsscience-technology-and-innovation-ministerial-meeting-brasilia-18-march2015-approved-documents>.

BRICS - BRASIL, RÚSSIA, ÍNDIA, CHINA E ÁFRICA DO SUL. Senior officials meeting of the BRICS member states on scientific and technological cooperation. Moscow: BRICS, 2011. Available at: <http://www.brics.utoronto. ca/docs/110915-science.html>.

First BRICS science, technology and innovation ministerial meeting: Cape Town declaration. [s.l.]: BRICS, 2014. Available at: <http://brics.utoronto.ca/docs>.

. Third BRICS science, technology and innovation ministerial meeting: Moscow declaration. [s.l.]: BRICS, 2015. Available at: <http:// infobrics.org/files/pdf/23.pdf>.

. Fourth BRICS science, technology and innovation ministerial meeting: Jaipur declaration. [s.l.]: BRICS, 2016.

- Fifth BRICS science, technology and innovation ministerial meeting: Hangzhou declaration. [s.l.]: BRICS, 2017a. Available at: <http:// www.iri.edu.ar/wp-content/uploads/2017/10/BO_Documentos_BRICS_5th_ BRICS_ScienceTechnologyInnovation.pdf>.

9. Available at: <http://brics-sti.org/index.php?p=new/20>. 
BRICS innovative competitiveness report 2017. [s.l.]: BRICS, $2017 \mathrm{~b}$. . Sixth BRICS science, technology and innovation ministerial meeting: Durban declaration. [s.l.]: BRICS, 2018. Available at: <https://www.dst.gov. za/images/BRICS-STI-Durban-Declaration-NEW-VERSION.docxFINALAGREED-VERSION.pdf>.

BRICS THINK TANKS COUNCIL. Towards a long-term strategy for BRICS: a proposal by the BRICS Think Tanks Council. Brasília: Ipea, 2015. Available at: <http://www.ipea.gov.br/portal/images/stories/PDFs/livros/livros/151104_ brics_long_term_strategy.pdf>.

EUREKA. EUREKA general presentation. [s.l.]: Eureka, 2015. Available at: <https:// www.eurekanetwork.org/sites/default/files/eureka-general-presentation.pdfs.

KAHN, M. A cooperação dos BRICS na ciência, tecnologia e inovação: retórica e realidades. Contexto Internacional, Rio de Janeiro, v. 37, n. 1, p. 185-213, 2015. Available at: <http://www.scielo.br/scielo.php?script=sci_arttext\&pid=S010285292015000100185\&lng=en\&nrm=iso>.

KUBOTA, L. C. O desempenho dos BRICS no Global Innovation Index 2018. Brasília: Ipea, 2018. Available at: <http://repositorio.ipea.gov.br/ bitstream/11058/8870/1/NT_14_Dinte_O_Desempenho.pdf>.

OECD - ORGANISATION FOR ECONOMIC CO-OPERATION AND DEVELOPMENT. OECD science, technology and industry scoreboard 2017: the digital transformation. Paris: OECD Publishing, 2017. Available at: https://www.oecd-ilibrary.org/science-and-technology/oecd-science-technologyand-industry-scoreboard-2017_9789264268821-en;jsessionid=fwcxCoRylG8h AVmQq5jcx23Z.ip-10-240-5-84

OKAMOTO, Y.; FUKASAKO, Y. APEC and innovation policy: lessons to learn from Europe. Kyoto: [s.n.], 2012. Available at: <https://doors.doshisha. ac.jp/duar/repository/ir/15807/019014020006.pdf>.

WANG, Y.; LI-YING, J. How do the BRIC countries play their roles in the global innovation arena? A study based on USPTO patents during 1990-2009. Scientometrics, v. 98, n. 2, p. 1065-1083, 2014.

\section{COMPLEMENTARY BIBLIOGRAPHY}

HUO, H.; WANG, Z.; LI, W. China report on science, technology and innovation. In: $\mathrm{ZHAO}, \mathrm{X}$. et al. BRICS innovative competitiveness report 2017: research series on the Chinese dream and China's development path. Singapore: [s.n.], 2018. p. 179-195. 
